\title{
ANALISIS BIOKONSENTRASI KADMIUM (Cd) PADA KERANG HIJAU (Perna viridis) DI PERAIRAN PONCOL, DESA BULU, KABUPATEN JEPARA, JAWA TENGAH
}

\author{
Bioconcentration Analysis of Cadmium (Cd) on Green Mussel in Poncol Coastal Water \\ Bulu Village, District of Jepara, Central Java
}

\section{Dwi Aprilia Rahma, Norma Afiati*) dan Siti Rudiyanti}

Program Studi Manajemen Sumberdaya Perairan, Departemen Sumberdaya Akuatik

Fakultas Perikanan dan Ilmu Kelautan, Universitas Diponegoro

J1. Prof. Soedarto, SH, Tembalang, Semarang, Jawa Tengah - 50275, Telp/Fax. +6224 7474698

Email : rdwiaprilia@gmail.com

\begin{abstract}
ABSTRAK
Poncol merupakan salah satu pesisir yang terdapat di Kabupaten Jepara. Meningkatnya aktivitas masyarakat di sekitar perairan Poncol memicu peningkatan konsentrasi limbah yang masuk ke dalam perairan. Salah satu limbah yang berbahaya adalah logam berat. Hal tersebut menjadi landasan dilakukannya penelitian mengenai analisis biokonsentrasi kadmium pada kerang hijau di perairan Poncol, Desa Bulu, Jepara. Penelitian ini dilaksanakan pada bulan Mei-Juni 2016, tujuan dari penelitian ini yaitu untuk mengetahui konsentrasi kadmium pada air dan jaringan lunak kerang hijau, dan untuk mengetahui angka faktor biokonsentrasi kadmium terhadap jaringan lunak kerang hijau. Metode yang digunakan adalah metode survei dengan penentuan lokasi sampling menggunakan teknik random sampling, 3 stasiun sampling yang sudah ditentukan yaitu, stasiun 1 di muara, stasiun 2 di perairan pantai dekat dengan keluarnya limbah dari kegiatan domestik, dan stasiun 3 di perairan pantai dekat dengan pemukiman warga dan tempat berlabuhnya perahu nelayan. Analisis kadmium pada air dan jaringan lunak kerang hijau dilakukan di Laboratorium BBTPPI, Semarang. Hasil perhitungan konsentrasi kadmium dalam air pada stasiun 1 diperoleh angka rata-rata sebesar 0,63 $\mu \mathrm{g} / \mathrm{ml}$, pada stasiun 2 sebesar $0,53 \mu \mathrm{g} / \mathrm{ml}$, dan pada stasiun 3 sebesar $0,64 \mu \mathrm{g} / \mathrm{ml}$. Konsentrasi kadmium dalam jaringan lunak kerang hijau pada stasiun 1 diperoleh angka rata-rata sebesar $0,91 \mu \mathrm{g} / \mathrm{mg}$, pada stasiun 2 sebesar $0,83 \mu \mathrm{g} / \mathrm{mg}$, dan pada stasiun 3 sebesar $0,93 \mu \mathrm{g} / \mathrm{mg}$. Hasil perhitungan angka bioconcentration factor (BCF) pada jaringan lunak kerang hijau berkisar antara 1,44 hingga 1,57. Berdasarkan hasil yang telah diperoleh dapat disimpulkan bahwa kadar konsentrasi kadmium pada air dan kerang hijau di perairan Poncol tergolong rendah dan masih berada di bawah ambang batas baku mutu. Angka bioconcentration factor logam berat kadmium pada jaringan lunak kerang hijau termasuk dalam kategori akumulatif rendah $(\mathrm{BCF}<100)$.
\end{abstract}

Kata Kunci : Biokonsentrasi; Logam Berat Kadmium; Kerang Hijau (P. viridis); Perairan Poncol - Jepara

\begin{abstract}
Poncol is one of the coastal areas in the district of Jepara. The increasing activity surrounding Poncol waters may increase the concentration of waste that flows into the waters. One of various hazardous wastes that way come into the coast is a heavy metal. Therefore it is needed to study the Analysis Bioconcentration Cadmium on Green Mussels in Poncol Waters, Bulu, Jepara. This work was conducted in May-June 2016. The purpose of this study to determine the concentration of the heavy metal cadmium both in the water and the soft tissue of green mussels, and further to measure the cadmium bioconcentration factor in the soft tissues. Survey method is used to determine random sampling points, 3 sampling stations that has been determined, at station 1 close to estuaries, at station 2 in coastal waters close to the disposal of wastewater from domestic activities, and at station 3 in coastal waters close to the residential area and close to berth of fishing boats. Analysis of cadmium in the water and the soft tissue of green mussels were conducted in Laboratory BBTPPI, Semarang. The result showed that Cd concentration in water at station 1 obtained an average rate are at $0.63 \mu \mathrm{g} / \mathrm{ml}$, at station 2 at $0.53 \mu \mathrm{g} / \mathrm{ml}$ and at station 3 at $0.64 \mu \mathrm{g} / \mathrm{ml}$. Cd concentration in the soft tissues of green mussels at Station 1 obtained an average rate of $0.91 \mu \mathrm{g} / \mathrm{mg}$, at station 2 at $0.83 \mu \mathrm{g} / \mathrm{mg}$, and at station $3 \mathrm{of} 0.93 \mu \mathrm{g} / \mathrm{mg}$. The result of the calculation of the value of bioconcentration factor (BCF) in soft tissue mussels ranged from 1.44 to 1.57. Based on the result, we can concluded that the levels of concentration of heavy metal cadmium in the water and the green mussels was low and below on quality standards. The rate of bioconcentration factor (BCF) of heavy metal cadmium in soft tissue green mussels was in the category of low accumulative $(B C F<100)$.
\end{abstract}

Keywords: Bioconcentration; Heavy Metal Cadmium; Green Mussels; Poncol Coastal Waters - Jepara

*)Penulis penanggungjawab 


\section{PENDAHULUAN}

Pesisir dikenal sebagai ekosistem perairan yang memiliki potensi sumberdaya yang sangat besar. Aktivitas ekonomi yang dilakukan di kawasan pesisir juga beragam di antaranya yaitu kegiatan penangkapan, budidaya perikanan, pariwisata, industri, kawasan pemukiman dan tempat membuang limbah. Menurut Putri (2012) ekosistem pesisir merupakan ekosistem yang memiliki kekayaan habitat yang berlimpah baik di darat maupun di laut. Beragam kegiatan ekonomi telah dijalankan di kawasan pesisir, sehingga dapat menyebabkan kerusakan ekosistem.

Poncol merupakan salah satu daerah pesisir di kabupaten Jepara. Masyarakat yang bermukim di kawasan ini memiliki ketergantungan terhadap sumber alam yaitu laut sebagai tempat mencari ikan dan melakukan budidaya, serta pantai sebagai tempat bertambatnya perahu. Salah satu sumberdaya perikanan yang melimpah di perairan Poncol yaitu kerang hijau ( $P$. viridis). Meningkatnya aktivitas masyarakat dapat memicu terjadinya pencemaran, yang menyebabkan peningkatan konsentrasi limbah yang masuk ke dalam perairan, sehingga dapat berdampak buruk pada kualitas air dan kehidupan organisme di dalamnya. Salah satu contoh limbah yang berbahaya berupa logam berat. Pencemaran logam di air dapat berasal dari proses alami atau aktivitas manusia yang berada di wilayah pesisir tersebut. Aktivitas manusia yang dapat menyebabkan terjadinya pencemaran logam yaitu jalur pelayaran kapal nelayan misalnya cat yang berasal dari perahu nelayan, kegiatan domestik berupa kegiatan rumah tangga, dan bengkel.

Pencemaran logam berat di perairan tidak hanya mencemari perairan, namun juga mempengaruhi biota akuatik. Logam berat dapat masuk ke dalam tubuh biota melalui proses bioakumulasi. Darmono (2010), menjelaskan bahwa seperti pada hewan air lainnya, logam berat dapat juga terakumulasi pada jaringan kerang. Perbedaannya, jenis kerang dapat mengakumulasi logam lebih besar daripada hewan air lainnya karena sifatnya yang menetap, lambat untuk bergerak menghindarkan diri dari pengaruh pencemar. Tujuan penelitian yang dilakukan pada bulan Mei - Juni 2016 ini yaitu untuk mengetahui konsentrasi logam berat kadmium pada air dan kerang hijau (P. viridis) dari perairan Poncol, desa Bulu, Jepara untuk dibandingkan dengan baku mutu yang dikeluarkan Keputusan Menteri L.H. No. 51 tahun 2004 , dan SNI 7387:2009, selain itu juga untuk mengetahui angka faktor biokonsentrasi logam berat kadmium terhadap jaringan lunak kerang hijau (P. viridis).

\section{MATERI DAN METODE PENELITIAN}

Variabel yang diamati meliputi logam berat kadmium pada air, dan jaringan lunak kerang hijau, suhu, salinitas, arus, $\mathrm{pH}$ dan oksigen terlarut di perairan Poncol, Jepara. Metode survei digunakan untuk menentukan lokasi sampling secara Random. Teknik tersebut adalah pengambilan sampel secara acak sederhana yang digunakan agar anggota populasi memiliki peluang yang sama besar untuk diambil sebagai sampel dan dapat mewakili sifat dan karakteristik dari setiap stasiun (Fachrul, 2007). Adapun titik sampling yang sudah ditentukan yaitu 3 stasiun, stasiun 1 di muara dekat dengan kegiatan pertambakan yang mendapatkan masukan air yang berasal dari aliran air sungai di sepanjang desa Bulu Jepara. Kerang hijau yang diambil berasal dari populasi alami. Stasiun 2 di perairan pantai sebelah utara dekat dengan keluarnya limbah dari kegiatan domestik. Stasiun 3 di perairan pantai sebelah timur dekat dengan pemukiman warga dan tempat berlabuhnya perahu nelayan. Sebaran titik sampling tersebut dapat dilihat pada Gambar 1 .

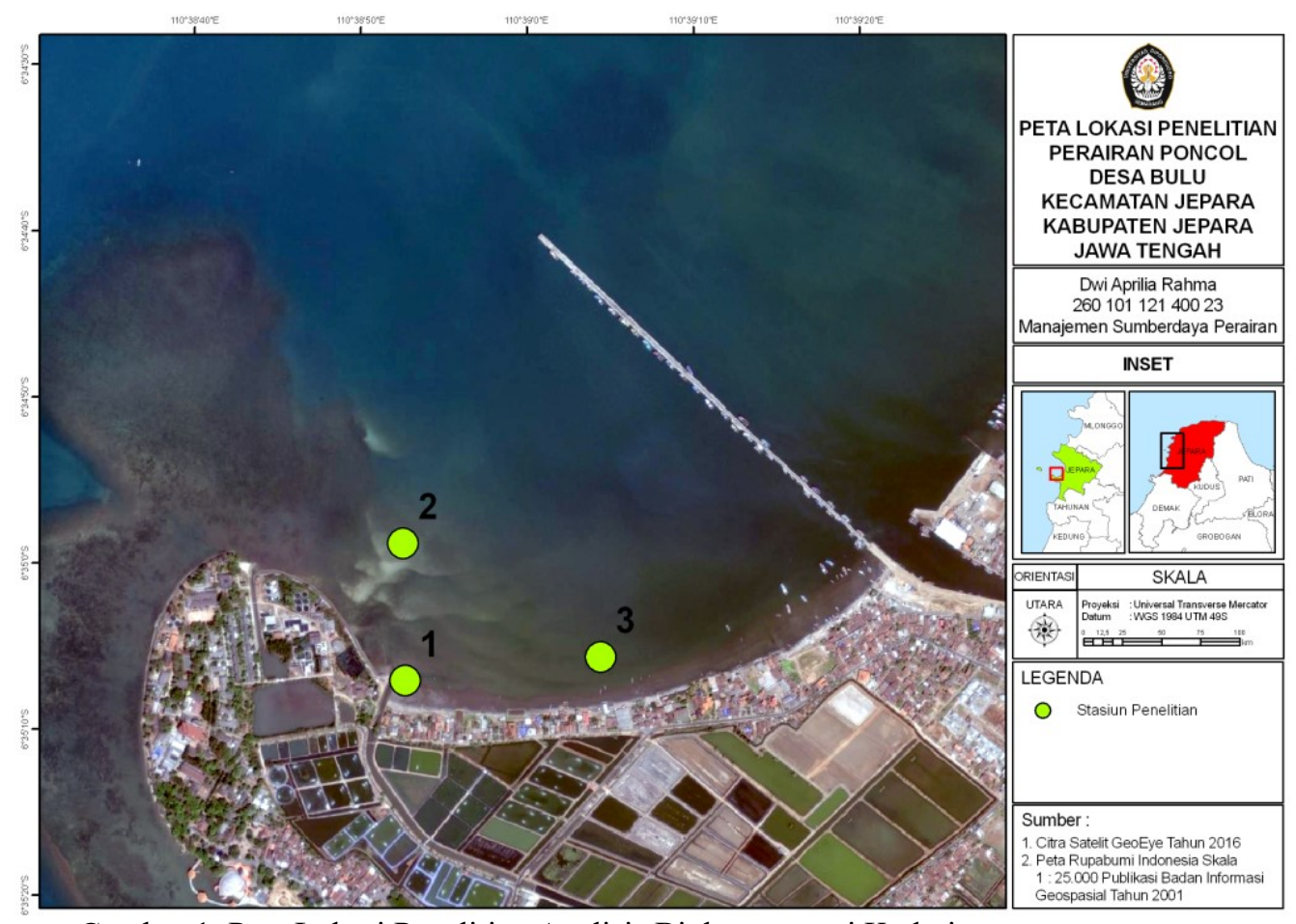

Gambar 1. Peta Lokasi Penelitian Analisis Biokonsentrasi Kadmium pada Air dan Kerang Hijau (P. viridis) 
Pengambilan sampel air logam kadmium sebanyak $1000 \mathrm{ml}$ dengan botol plastik $1000 \mathrm{ml}$, mengacu pada SNI 6989-59-2008, dilakukan secara grab samples (sesaat) yaitu mengambil sampel air secara horizontal di permukaan dengan melawan arus. Sampel air yang digunakan untuk analisis logam berat kadmium diawetkan dengan menambahkan asam nitrat $\left(\mathrm{HNO}_{3}\right) 65 \%$ sampai $\mathrm{pH}<2$. Setelah itu botol sampel ditutup, diberi label disimpan ke dalam cool box.

Spesimen kerang hijau diambil secara manual dari masing-masing stasiun, dengan bantuan nelayan setempat. Spesimen kerang hijau diambil dari perairan sebanyak \pm 500 gram, dengan berat jaringan lunak \pm 150 gram untuk memenuhi persyaratan yang diminta Laboratorium Balai Besar Teknologi Pencegahan Pencemaran Industri (BBTPPI) yaitu minimal 100 gram. Pengambilan jaringan lunak kerang hijau dilakukan di lapangan segera setelah kerang spesimen didaratkan. Tanpa dicuci terlebih dahulu, kerang hijau dibuka menggunakan tangan dan jaringan lunaknya diambil menggunakan pinset. Jaringan lunak kerang hijau kemudian dimasukkan ke dalam plastik ziplock yang telah diberi label kode sampling dan disimpan ke dalam cool box.

Sampel air dan jaringan lunak kerang hijau yang telah didapat kemudian dibawa ke Laboratorium Balai Besar Teknologi Pencegahan Pencemaran Industri (BBTPPI) Semarang, untuk dianalisis kandungan logam berat kadmium. Posedur pengukuran konsentrasi kadmium pada sampel air dan kerang hijau mengacu APHA, AWWA, WEF (2012), dengan menggunakan AAS dengan merk Agilent Technologies 200 Series AA Ultra UV dan merk Shimadzu series AA7000 .

Konsentrasi logam berat yang telah diperoleh dilakukan analisis data secara inferensi yaitu membandingkan kandungan logam dalam air dan jaringan lunak kerang hijau dengan baku mutu, yang ditampilkan pada Tabel 1:

Tabel 1. Batas maksimum cemaran logam berat $\mathrm{Cd}$

\begin{tabular}{c|c|c}
\hline Jenis Logam & $\begin{array}{c}\text { Kadar maksimum dalam Kekerangan } \\
\text { (bivalve) }(\mathbf{m g} / \mathbf{k g}) *\end{array}$ & $\begin{array}{c}\text { Kadar maksimum dalam air } \\
(\mathbf{m g} / \mathbf{l}) * *\end{array}$ \\
\hline $\mathrm{Cd}$ & 1,0 & 0,001 \\
\hline
\end{tabular}

Keterangan:

*SNI 7387:2009 tentang Batas Maksimum Cemaran Logam Berat dalam Pangan;

** Keputusan Menteri L.H. No. 51 tahun 2004 tentang Baku Mutu Air Laut untuk Biota Air Laut.

Menurut LaGrega et al., (2001) dalam Hidayah et al., (2014) faktor biokonsentrasi merupakan kecenderungan suatu bahan kimia yang diserap oleh organisme akuatik. BCF merupakan rasio antara konsentrasi bahan kimia dalam organisme akuatik dengan konsentrasi bahan kimia di dalam air. Analisis data dilakukan menggunakan formulasi:

Dimana:

$$
\mathrm{BCF}=\mathrm{C}_{\text {org }} / \mathrm{C}
$$

$\mathrm{C}_{\text {org }} \quad=$ Konsentrasi logam berat dalam organisme $(\mathrm{mg} / \mathrm{kg}$ atau $\mathrm{ppm})$

$\mathrm{C}=$ Konsentrasi logam berat dalam air $(\mathrm{mg} / \mathrm{l}$ atau $\mathrm{ppm})$

Berdasarkan kategori nilai BCF sifat pencemar dibagi ke dalam tiga urutan, yaitu:

$\mathrm{BCF}>1000 \quad=$ sangat akumulatif

$\mathrm{BCF} 100-1000=$ akumulatif sedang

$\mathrm{BCF}<100 \quad=$ akumulatif rendah

\section{HASIL DAN PEMBAHASAN}

Hasil

a. Parameter Lingkungan Lokasi Penelitian

Parameter lingkungan dapat memberikan pengaruh yang cukup besar, baik terhadap angka konsentrasi logam di perairan ataupun keberadaan kerang hijau ( $P$. viridis) yang dijadikan sebagai objek penelitian di setiap stasiun sampling. Parameter lingkungan yang diukur pada penelitian analisis biokonsentrasi logam berat kadmium pada kerang hijau $(P$. viridis) ini yaitu suhu, arus, salinitas, $\mathrm{pH}$ dan oksigen terlarut. Berdasarkan pengukuran parameter lingkungan pada setiap stasiun diperoleh hasil yang tersaji pada Tabel $2-4$.

Tabel 2. Parameter Lingkungan pada Stasiun I di Pesisir Poncol, Desa Bulu, Jepara

\begin{tabular}{|c|c|c|c|c|}
\hline \multirow{2}{*}{$\begin{array}{c}\text { Parameter } \\
\text { Lingkungan }\end{array}$} & \multicolumn{3}{|c|}{ Stasiun I } & \multirow[b]{2}{*}{ Rata-rata } \\
\hline & $14 / 05 / 2016$ & $21 / 05 / 2016$ & $28 / 05 / 2016$ & \\
\hline Suhu $\left({ }^{\circ} \mathrm{C}\right)$ & 32 & 32 & 30 & 31 \\
\hline Kecepatan Arus (m/s) & 0,03 & 0 & 0,02 & 0,016 \\
\hline Salinitas (\%o) & 27 & 27 & 27 & 27 \\
\hline $\mathrm{pH}$ & 7 & 7 & 7 & 7 \\
\hline $\mathrm{DO}(\mathrm{mg} / \mathrm{l})$ & 4,8 & 4 & 4,4 & 4,4 \\
\hline
\end{tabular}

${ }^{\circ}$ Copyright by Management of Aquatic Resources (MAQUARES) 
Tabel 3. Parameter Lingkungan pada Stasiun II di Pesisir Poncol, Desa Bulu, Jepara

\begin{tabular}{ccccc}
\hline Parameter & \multicolumn{4}{c}{ Stasiun II } \\
\cline { 2 - 5 } Lingkungan & $\mathbf{1 4 ~ / ~ 0 5 ~ / ~ 2 0 1 6 ~}$ & $\mathbf{2 1 ~ / ~ 0 5 / ~ 2 0 1 6}$ & $\mathbf{2 8}$ / 05 / 2016 & Rata-rata \\
\hline Suhu $\left({ }^{\circ} \mathrm{C}\right)$ & 32 & 32 & 30 & 31 \\
Kecepatan Arus (m/s) & 0,04 & 0,07 & 0,02 & 0,043 \\
Salinitas (\%o) & 29 & 29 & 29 & 28 \\
$\mathrm{pH}$ & 7 & 7 & 7 & 7 \\
DO (mg/l) & 3,4 & 3,6 & 4 & 3,6 \\
\hline
\end{tabular}

Tabel 4. Parameter Lingkungan pada Stasiun III di Pesisir Poncol, Desa Bulu, Jepara

\begin{tabular}{ccccc}
\hline Parameter & \multicolumn{4}{c}{ Stasiun III } \\
\cline { 2 - 5 } Lingkungan & $\mathbf{1 4 / 0 5 / 2 0 1 6}$ & $\mathbf{2 1} / \mathbf{0 5} / \mathbf{2 0 1 6}$ & $\mathbf{2 8}$ / 05 / 2016 & Rata-rata \\
\hline Suhu $\left({ }^{\circ} \mathrm{C}\right)$ & 32 & 32 & 30 & 31 \\
Kecepatan Arus $(\mathrm{m} / \mathrm{s})$ & 0,04 & 0,02 & 0,06 & 0,04 \\
Salinitas $(\% \mathrm{o})$ & 30 & 30 & 30 & 30 \\
$\mathrm{pH}$ & 7 & 7 & 7 & 7 \\
DO $(\mathrm{mg} / \mathrm{l})$ & 3,6 & 3,2 & 4 & 3,6 \\
\hline
\end{tabular}

\section{b. Konsentrasi Logam Cd dalam Air}

Hasil perhitungan konsentrasi logam berat kadmium dalam air di pesisir Poncol, Desa Bulu, Jepara pada stasiun 1 diperoleh angka rata-rata sebesar $0,63 \mu \mathrm{g} / \mathrm{ml}$, pada stasiun 2 sebesar $0,53 \mu \mathrm{g} / \mathrm{ml}$ dan pada stasiun 3 sebesar 0,64 $\mu \mathrm{g} / \mathrm{ml}$. Hasil konsentrasi logam berat kadmium dapat dilihat pada Tabel 5:

Tabel 5. Konsentrasi logam berat Cd dalam air di Pesisir Poncol

\begin{tabular}{ccccc}
\hline \multirow{2}{*}{ Ulangan } & \multicolumn{2}{c}{ Konsentrasi Logam Berat Kadmium $(\boldsymbol{\mu g} / \mathbf{m l})$} & \multirow{2}{*}{ Keputusan Menteri L.H No. } \\
\cline { 2 - 4 } & Stasiun 1 & Stasiun 2 & Stasiun 3 & \\
\hline I & 0,67 & 0,56 & 0,70 & Tahun 2004 \\
II & 0,58 & 0,50 & 0,60 & $1 \mu \mathrm{g} / \mathrm{ml}$ \\
III & 0,65 & 0,52 & 0,63 & $1 \mu \mathrm{g} / \mathrm{ml}$ \\
Rataan & 0,63 & 0,53 & 0,64 & $1 \mu \mathrm{g} / \mathrm{ml}$ \\
\hline
\end{tabular}

Keterangan: *1 $\mu \mathrm{g} / \mathrm{ml}=0,001 \mathrm{mg} / \mathrm{l}$. Baku Mutu Logam Berat (mg/l) pada Air Laut Berdasarkan Keputusan Menteri L.H. No. 51 tahun 2004 tentang Baku Mutu Air Laut untuk Biota Air Laut.

Dari hasil analisis terlihat bahwa angka konsentrasi logam berat kadmium dalam air dari pesisir Poncol Jepara masih berada di bawah baku mutu yang ditetapkan Keputusan Menteri L.H. No. 51 tahun 2004.

\section{c. Konsentrasi Logam Cd dalam Jaringan Lunak Kerang Hijau ( $P$. viridis)}

Hasil perhitungan konsentrasi logam berat $\mathrm{Cd}$ dalam jaringan lunak kerang $(P$. viridis) hijau di perairan Hasil perhitungan konsentrasi logam berat kadmium dalam jaringan lunak kerang ( $P$. viridis) hijau di pesisir Poncol, Desa Bulu, Jepara pada stasiun 1 diperoleh angka rata-rata sebesar $0,91 \mu \mathrm{g} / \mathrm{kg}$. Stasiun 2 diperoleh angka rata-rata sebesar 0 , $83 \mu \mathrm{g} / \mathrm{kg}$. Stasiun 3 diperoleh angka rata-rata sebesar $0,93 \mu \mathrm{g} / \mathrm{kg}$. Hasil konsentrasi logam berat kadmium dapat dilihat pada Tabel 6:

Tabel 6. Konsentrasi logam berat Cd dalam jaringan lunak kerang hijau ( $P$. viridis) di pesisir Poncol

\begin{tabular}{ccccc}
\hline \multirow{2}{*}{ Ulangan } & \multicolumn{2}{c}{ Konsentrasi Logam Berat Kadmium $(\boldsymbol{\mu g} / \mathbf{m g})$} & \multirow{2}{*}{ SNI 7387:2009* } \\
\cline { 2 - 4 } & Stasiun 1 & Stasiun 2 & Stasiun 3 & \\
\hline I & 0,94 & 0,94 & 0,96 & $1000 \mu \mathrm{g} / \mathrm{mg}$ \\
II & 0,88 & 0,80 & 0,89 & $1000 \mu \mathrm{g} / \mathrm{mg}$ \\
III & 0,91 & 0,91 & 0,94 & $1000 \mu \mathrm{g} / \mathrm{mg}$ \\
\hline Rataan & 0,91 & 0,83 & 0,93 & \\
\hline
\end{tabular}

Keterangan: *1,0 mg/kg=1000 $\mu \mathrm{g} / \mathrm{mg}$. Baku Mutu Logam Berat (mg/l) Berdasarkan SNI 7387:2009 tentang Batas Maksimum Cemaran Logam Berat dalam Pangan.

Dari hasil analisis terlihat bahwa angka konsentrasi logam berat kadmium dalam jaringan lunak kerang hiaju dari pesisir Poncol Jepara masih berada di bawah baku mutu berdasarkan SNI 7387:2009. 


\section{d. Biokonsentrasi Faktor Logam Berat Cd pada Jaringan Lunak Kerang Hijau}

Berdasarkan hasil perhitungan angka bioconcentration factor (BCF) pada jaringan lunak kerang hijau di perairan Poncol desa Bulu, Jepara maka angka BCF logam berat kadmium pada jaringan lunak kerang hijau dapat dilihat pada Tabel 7:

Tabel 7. Angka BCF Logam Berat Cd pada Jaringan Lunak Kerang Hijau (P. viridis)

\begin{tabular}{cccc}
\hline Stasiun & $\begin{array}{c}\text { Kandungan kadmium } \\
\text { pada Air }(\boldsymbol{\mu g} / \mathbf{m l})\end{array}$ & $\begin{array}{c}\text { Kandungan kadmium pada jaringan } \\
\text { lunak kerang hijau }(\boldsymbol{\mu g} / \mathbf{m g})\end{array}$ & Angka BCF \\
\hline 1 & 0,63 & 0,91 & 1,44 \\
2 & 0,53 & 0,83 & 1,57 \\
3 & 0,64 & 0,93 & 1,45 \\
\hline
\end{tabular}

Berdasarkan perhitungan faktor biokonsentrasi logam berat kadmium pada jaringan lunak kerang hijau $(P$. viridis) diperoleh angka $\mathrm{BCF}$ dengan kisaran $1,44-1,57$, hasil tersebut menunjukkan $\mathrm{BCF}<100$ atau bersifat akumulatif rendah.

\section{Pembahasan}

Angka konsentrasi logam berat kadmium di setiap stasiun, dipengaruhi oleh jenis limbah yang dikeluarkan dan jarak antara titik sampling dengan sumber cemaran. Keberadaan limbah-limbah organik maupun anorganik, sebagian besar berasal dari limbah rumah tangga yang banyak menumpuk di sekitar muara dan sepanjang pesisir. Selain limbah seperti sampah plastik, kaca, kayu, styrofoam, masyarakat juga mencemari perairan dengan membuang limbah domestik ke perairan.

Berdasarkan sampling yang telah dilakukan di perairan Poncol, keberadaan kerang hijau ( $P$. viridis) cukup melimpah, baik di muara maupun di pesisir pantai. Hal tersebut juga dinyatakan oleh penduduk sekitar bahwa kerang hijau (P. viridis) banyak didapatkan di perairan Jepara, baik kerang hijau yang tumbuh alami di alam, ataupun kerang hijau yang dibudidaya di lokasi tersebut.

Semua limbah, baik itu limbah domestik ataupun limbah industri dibedakan atas kelompok limbah kimia organik dan anorganik. Limbah kimia organik dalam rentang waktu yang cukup panjang masih dapat diuraikan oleh mikroorganisme, untuk kemudian digunakan kembali, walaupun ada limbah kimia organik jenis lain yang sukar mengalami proses daur ulang, seperti sampah plastik. Di samping itu senyawa-senyawa kimia anorganik yang mengandung unsur logam berat, meski dapat terurai menjadi senyawa-senyawa sederhana, akan tetapi menjadi limbah beracun yang dapat merugikan manusia (Palar, 2008)

Konsentrasi logam berat kadmium pada air di pesisir Poncol, Desa Bulu, Jepara menunjukkan angka yang sangat rendah. Angka konsentrasi logam berat kadmium yang diperoleh berada di bawah ambang batas baku mutu air laut (Tabel 5), yang ditetapkan Keputusan Menteri L.H. No. 51 Tahun 2004, tentang Baku Mutu Air Laut untuk Biota Air Laut yaitu $1 \mu \mathrm{g} / \mathrm{ml}$. Menurut Munce (1990) dalam Akbar et al., (2014) rendahnya konsentrasi logam diduga karena pergerakan air laut yang dinamis yang dipengaruhi oleh beberapa faktor fisika seperti angin, arus, gelombang dan pasang surut sehingga terjadi pengenceran yang terus menerus yang mengakibatkan rendahnya kandungan logam berat pada daerah perairan estuari.

Menurut Effendi (2003), konsentrasi kadmium perairan laut sekitar 0,0001 mg/l. Untuk melindungi kehidupan ekosistem akuatik, perairan memiliki kadar kadmium $0,0002 \mathrm{mg} / \mathrm{l}$. Hal tersebut karena kadmium bersifat sangat toksik dan bioakumulatif terhadap organisme. Darmono (1995), menyatakan bahwa laju pertambahan kandungan logam erat hubungannya dengan konsentrasi logam dalam air. Namun hal itu tidak menjamin bahwa kandungan logam pada air mencerminkan kandungan logam pada jaringan organisme.

Konsentrasi logam berat kadmium kerang hijau memiliki angka konsentrasi yang sangat rendah dan berada di bawah batas maksimum (Tabel 6), yang ditetapkan SNI 7387:2009 tentang Batas Maksimum Cemaran Logam dalam Pangan yaitu sebesar $1000 \mu \mathrm{g} / \mathrm{mg}$. Meskipun angka konsentrasi logam berat kadmium pada air rendah, tetapi angka yang terdapat pada kerang hijau terlihat lebih tinggi. Hal tersebut kemungkinan karena kadmium dalam air terakumulasi secara terus menerus di tubuh kerang hijau ( $P$. viridis) sehingga terjadi peningkatan konsentrasi logam berat kadmium. Menurut Afiati (2005), konsentrasi yang mematikan dari logam bagi organisme laut pada kenyataannya cukup tinggi jika dibandingkan dengan konsentrasi logam di dalam air. Bagaimanapun juga, hasil kumulatif dari konsentrasi logam di dalam air menjadi berbahaya karena pada keadaan organik kebanyakan dari logam tersebut menjadi beracun dan relatif tidak dapat diurai. Darmono (1995) menjelaskan bahwa, kadmium merupakan salah satu logam berat yang tidak diregulasi. Logam yang tidak teregulasi adalah logam yang secara terus menerus terakumulasi oleh jaringan organisme. Kandungannya naik secara terus menerus sesuai kenaikan konsentrasi logam di air, dan logam ini hanya diekresi sedikit sekali.

Dari hasil pengukuran parameter lingkungan di perairan Poncol (Tabel 2-4), menunjukkan bahwa kandungan oksigen terlarut yang diperoleh cenderung rendah, oksigen terlarut yang rendah tersebut kemungkinan dapat mempercepat proses biokonsentrasi logam kadmium pada kerang hijau. Menurut Connel dan Miller (1995) dalam Syakti et al., (2012) rendahnya kondisi oksigen terlarut dalam air dapat mengakibatkan stres fisologik pada biota, 
sehingga dapat meningkatkan respirasi. Hal tersebut akan mempercepat proses biokonsentrasi dan meningkatkan toksisitas logam berat dalam tubuh biota.

Logam berat kadmium merupakan logam non-essential yang keberadaanya dalam tubuh makhluk hidup dapat dikatakan tidak diharapkan. Angka faktor biokonsentrasi logam kadmium pada jaringan lunak kerang hijau (P.viridis) di perairan Poncol berkisar 1,44-1,57. Berdasarkan hasil tersebut faktor biokonsentrasi logam berat kadmium pada jaringan lunak kerang hijau ( $P$. viridis) termasuk dalam kategori akumulatif rendah. Van Esch (1977) dalam Suprapti (2008) mengelompokkan sifat pencemar berdasarkan kategori angka BCF ke dalam tiga urutan yaitu: sangat akumulatif (BCF > 1000), akumulatif sedang (BCF 100 - 1000), dan akumulatif rendah (BCF < 100). Menurut Pourang et al., (2010) logam kadmium (Cd) merupakan elemen yang tidak diharapkan oleh Moluska. Akumulasi logam kadmium (Cd) relatif rendah hal tersebut mungkin karena adanya mekanisme detoksifikasi logam berat dalam invertebrata air.

Tingkat akumulatif logam berat kadmium (Cd) masih berada di tingkat aman, tetapi angka tersebut perlu untuk diwaspadai karena menurut Nasution (2011) dalam Partogi et al., (2014), logam berat mempunyai sifat mudah mengikat bahan organik, dimana dengan proses filter feeder saat makanan tersebut masuk ke dalam tubuh kerang, maka partikel logam berat akan ikut terserap ke dalam tubuh, sehingga makin banyak makanan yang disaring maka semakin banyak juga logam berat terakumulasi dalam tubuh kerang. Turgeon (1998) dalam Emilia (2015), menjelaskan bahwa biota perairan jenis Moluska dan Bivalvia mampu menyaring air ke dalam cangkangnya sebanyak $300 \mathrm{ml}$ dalam jangka waktu 1 jam, karena cara makan jenis kekerangan dengan cara menyaring makanan.

Namun demikian, hal tersebut tetap harus diwaspadai karena ada kemungkinan konsentrasi logam berat kadmium di lingkungan perairan Poncol, Jepara dapat meningkat. Oleh karenanya meskipun hasil penelitian menunjukan nilai logam kadmium ini masih dalam batas aman, tetap harus diperhatikan karena konsentrasi logam kadmium terhadap logam kadmium ini bersifat akumulatif rendah dan dapat menyebabkan keracunan kronis.

Menurut Palar (2008), keracunan yang bersifat kronis yang disebabkan oleh daya racun yang dibawa oleh logam kadmium, terjadi dalam selang waktu yang sangat panjang. Peristiwa ini terjadi karena logam kadmium masuk ke dalam tubuh dalam jumlah kecil, sehingga dapat ditolerir oleh tubuh. Akan tetapi karena proses kemasukan yang terusmenerus secaraberkelanjutan maka tubuh pada batas akhir tidak lagi mampu memberikan toleransi terhadap daya racun yang dibawa oleh kadmium. Keracunan kronis yang disebabkan oleh kadmium umumnya berupa kerusakan-kerusakan pada banyak sistem fisiologis. Sistem-sistem tubuh yang dapat dirusak oleh keracunan kadmium yaitu pada sistem urinaria (ginjal), sistem respirasi (paru-paru), dan sistem sirkulasi darah (jantung).

\section{KESIMPULAN}

Kesimpulan yang diperoleh dari kegiatan penelitian ini yaitu:

1. Konsentrasi logam berat kadmium pada air di pesisir Poncol, Desa Bulu, Jepara berkisar antara $0,50 \mu \mathrm{g} / \mathrm{ml}$ hingga $0,70 \mu \mathrm{g} / \mathrm{ml}$ sehingga masih tergolong rendah dan berada di bawah ambang batas baku mutu yang ditetapkan Keputusan Menteri L.H. No. 51 Tahun 2004, tentang Baku Mutu Air Laut untuk Biota Air Laut yaitu $1 \mu \mathrm{g} / \mathrm{ml}$.

2. Konsentrasi logam berat kadmium dalam jaringan lunak kerang hijau ( $P$. viridis) dari perairan Poncol, Jepara berkisar antara $0,80 \mu \mathrm{g} / \mathrm{mg}$ hingga $0,96 \mu \mathrm{g} / \mathrm{mg}$, hal tersebut menunjukkan konsentrasi logam berat kadmium masih berada di bawah batas maksimum yang ditetapkan SNI 7387:2009 tentang Batas Maksimum Cemaran Logam Berat dalam Pangan yaitu $1000 \mu \mathrm{g} / \mathrm{mg}$.

3. Hasil penelitian menunjukkan bahwa angka bioconcentration factor (BCF) logam berat kadmium pada jaringan lunak kerang hijau $(P$. viridis) berkisar antara 1,44 hingga 1,57 termasuk dalam kategori akumulatif rendah (BCF $<100)$.

\section{UCAPAN TERIMA KASIH}

Penulis mengucapkan terima kasih kepada Drs. Ign. Boedi Hendrarto, M.Sc. PhD, Churun Ain, S.Pi. M.Si., dan Dr. Ir. Bambang Sulardiono, MS selaku tim penguji yang telah memberikan arahan, bimbingan, serta kritik dan saran dalam penyusunan jurnal ini.

\section{DAFTAR PUSTAKA}

Afiati, N. 2005. Bioaccumulation of Trace Metals in The Blood Clam Anadara granosa (Arcidae) and Their Implications for Indicator Studies. Second International Seminar on Environment Chemistry and Toxicology, 26-27 April 2005. Yogyakarta.

Akbar A. W., A. Daud, dan A. Mallongi. 2014. Analisis Risiko Lingkungan Logam Berat Cadmium (Cd) pada Sedimen Air Laut di Wilayah Pesisir Kota Makassar. Fakultas Kesehatan Masyarakat. Universitas Hasanuddin Makasar.

BSN. 2008. SNI 6989.59-2008 Tentang Metoda Pengambilan Contoh Air Limbah. Jakarta.

2009. SNI 7387:2009 Tentang Batas Maksimum Cemaran Logam Berat Dalam Pangan. Jakarta

Connel, D.W. and G. J. Miller. 2006. Kimia dan Ekotoksikologi Pencemaran. Y. Koestoer (Penerjemah). Universitas Indonesia Press. Jakarta. $520 \mathrm{hlm}$.

Darmono. 1995. Logam dalam Sistem Biologi Makhluk Hidup. UI Press, Jakarta. 140 hlm.

2010. Lingkungan Hidup dan Pencemaran. Hubungan dengan Toksikologi Senyawa Logam. Universitas Indonesia (UI) Press: Jakarta. 179 hlm.

\footnotetext{
${ }^{\circ}$ Copyright by Management of Aquatic Resources (MAQUARES)
} 
Emilia, I. 2015. Biokonsentrasi Logam Kadmium (Cd) Dalam Jaringan Remis (Corbicula Sp.) Terhadap Lingkungan Abiotik (Air Dan Sedimen) Di Perairan Sungai Musi Kota Palembang. Sainmatika. 12(1): 25-31.

Effendi, H. 2003. Telaah Kualitas Air bagi Pengelolaan Sumber Daya dan Lingkungan Perairan. Kanisius, Yogyakarta. $258 \mathrm{hlm}$.

Fachrul, M. F. 2007. Metode Sampling Bioekologi. PT Bumi Aksara, Jakarta, 198 hlm.

Hidayah, A. M., Purwanto, dan T. P. Soeprobowati. 2014. Biokonsentrasi Faktor Logam Berat Pb, Cd, Cr, dan Cu pada Ikan Nila (Oreochromis niloticus Linn.) di Karamba Danau Rawa Pening. Bioma. 16(1):1-9.

Keputusan Menteri Lingkungan Hidup nomor 51 tahun 2004 tentang Baku Mutu Air Laut untuk Biota Air Laut.

Palar, H. 2008. Pencemaran dan Toksikologi Logam Berat. Rineka Cipta, Jakarta. $152 \mathrm{hlm}$.

Pertogi, M. A., P. A. Purnomo, dan Suryanti. 2014. Distribusi Logam Berat Timbal $(\mathrm{Pb})$ dan Cadmium $(\mathrm{Cd})$ di Sedimen, Air dan Bivalvia di Lingkungan Muara Sungai Wiso Jepara. Diponegoro Journal of Maquares. 4(3): 92-101.

Pourang, N., C. A. Richardson, dan M. S. Mortazavi. 2010. Heavy Metal Concentrations in the Soft Tissues of Swan Mussel (Anadonta cygnea) and Surficial Sediments from Anzali Wetland, Iran. Environ Monit Assess. 163:195213.

Putri R. A., T. Haryono., dan S. Kuntjoro. 2012. Keanekaragaman Bivalvia Dan Peranannya Sebagai Bioindikator Logam Berat Kromium (Cr) Di Perairan Kenjeran, Kecamatan Bulak Kota Surabaya. LenteraBio. 1(2): 87-91.

Rudiyanti, S. 2007. Biokonsentrasi Kerang Darah (Anadara Granosa Linn) terhadap Logam Berat Cadmium (Cd) yang Terkandung Dalam Media Pemeliharaan yang Berasal dari Perairan Kaliwungu, Kendal. Jurnal Penelitian. Universitas Diponegoro Semarang. $12 \mathrm{hlm}$.

Suprapti. 2008. Kandungan Chromium pada Perairan, Sedimen dan Kerang Darah (Anadara granosa) di Wilayah Pantai Sekitar Muara Sayung Desa Morosari Kabupaten Demak, Jawa Tengah. Bioma. 10(2): 36-40. 